\title{
Integration of pen aquaculture in ecosystem-based enhancement of small-scale fisheries in a macrophyte dominated floodplain wetland of India
}

\section{Gunjan Karnatak}

Central Inland Fisheries Research Institute

Basanta Kumar Das ( $\square$ basantakumard@gmail.com )

Central Inland Fisheries Research Institute https://orcid.org/0000-0002-6629-8992

Uttam Kumar Sarkar

Central Inland Fisheries Research Institute

Simanku Borah

Central Inland Fisheries Research Institute

Aparna Roy

Central Inland Fisheries Research Institute

\section{Pranay Parida}

Central Inland Fisheries Research Institute

Lianthuamluaia Lianthuamluaia

Central Inland Fisheries Research Institute

\section{Archan Kanti Das}

Central Inland Fisheries Research Institute

\section{Bijay Kumar Behera}

Central Inland Fisheries Research Institute

Arun Pandit

Central Inland Fisheries Research Institute

\section{Amiya Kumar Sahoo}

Central Inland Fisheries Research Institute

Birendra Kumar Bhattacharjya

Central Inland Fisheries Research Institute

Sangeeta Chakraborty

Central Inland Fisheries Research Institute

\section{Purna Chandra}

Central Inland Fisheries Research Institute 
Keywords: Wetland, pen aquaculture, macrophyte management, grass carp, small-scale fisheries

Posted Date: March 7th, 2022

DOI: https://doi.org/10.21203/rs.3.rs-1329220/v1

License: (c) (1) This work is licensed under a Creative Commons Attribution 4.0 International License. Read Full License 


\section{Abstract}

The rapid degradation, overexploitation and encroachment of floodplain wetlands have led to considerable decline in fish diversity and production from these invaluable aquatic resources threatening livelihood of the dependent fishers. The climate change evident in the fast few decades have further aggravated the problem of eutrophication causing water stress, sedimentation leading to rampant macrophyte proliferation affecting ecological and economic functioning of these ecosystems. Macrophyte control and management needs serious attention for sustaining ecosystem services provided by these resources. In this direction pen culture of grass carp, Ctenopharyngodon idella as a biocontrol for macrophytes along with Indian major carps was implemented in a co-management mode in Beledanga, a typical floodplain wetland, a gradually shrinking, macrophyte dominated floodplain wetland in lower Ganga basin. Indian major carps Labeo catla $(6.28 \pm 0.23 \mathrm{~g})$, Labeo rohita $(5.1 \pm 0.12 \mathrm{~g})$, Cirrhinus mrigala (3.5 $\pm 0.08 \mathrm{~g})$ were stocked in the ratio $4: 3: 3$ at the rate of $20 \mathrm{no} . / \mathrm{m}^{2}$ in pens ( 0.1 ha each) in triplicate. Grass carp $(7.1 \pm 0.42 \mathrm{~g})$ was stocked in pen at the rate of $20 \mathrm{no} . / \mathrm{m}^{2}$. The fishes were fed with pelleted feed twice a day at the rate of $2-3 \%$ of body weight per day. The seed was overwintered in pens for a period of 90 days from November 2019-January 2020. Average weight recorded at the end of culture period was $25.13 \pm 1.70 \mathrm{~g}, 18.11 \pm 0.63 \mathrm{~g}, 14.53 \pm 0.87 \mathrm{~g}$ and $39.20 \pm 1.90 \mathrm{~g}$ in L. catla, L. rohita, C. mrigala and C. idella respectively. The survival of fish ranged from 70 to $81 \%$. Growth performance and feed utilization efficiency of grass carp was significantly higher $(p<0.05)$ compared to other carp species. The pen culture was found to be economically viable with a benefit cost ratio of 1.53 . The fishes produced were released back into the open wetland as an input for culture based fisheries. The intervention led to $24 \%$ increase in the fish production from the wetland with grass carp contributing $20-22 \%$ of the total catch with $32 \%$ increase in revenue generated by the sale of fish with in a short span of one year. The study successfully demonstrated technological suitability and economic feasibility of pen culture in this wetland and role of grass carp as a potential biocontrol species for macrophyte management. Grass carp stocked grew to 0.8 to $1 \mathrm{~kg}$ within 6 month and $2-2.3 \mathrm{~kg}$ within a year and could utilise $40-45 \%$ of the submerged and emergent macrophytes. Integration and optimization of grass carp will not only aid in habitat management of macrophyte-choked wetlands but will also boost their small-scale fisheries by converting standing macrophyte biomass into protein rich fish biomass. The enhanced production will also cater to nutritional and livelihood security of the dependent fishers.

\section{Introduction}

India has vast floodplain wetland resources ( 0.5 million ha) distributed mainly in the Eastern and North Eastern States. These resources provide multiple goods and ecological services to resource poor fishers (MEA, 2005) besides providing habitat for fishes (Jude and Pappas 1992; Trebitz and Hoffman 2015) maintaining water quality (Sierszen et al. 2012) and acting as a carbon sink (Nag et al. 2019). They are one of the most productive fisheries resources having production potential of $1500-2000 \mathrm{~kg} / \mathrm{ha} / \mathrm{year}$ (Sarkar et al. 2016). They harbor rich fish diversity (96 fish species) and are important spawning and 
nursery ground to many commercially important riverine fish species and contribute significantly to the nutritional as well as livelihood security of the rural mass (Sarkar et al. 2021a).

In recent years, the fish production and diversity from wetlands has rapidly declined owing to anthropogenic and other environmental challenges (Sarkar and Borah 2018; Sarkar et al. 2020b) threating livelihood of the dependent fishers (Sarkar et al. 2021a). The climatic variability and uncertainties have further aggravated the threats affecting fisheries production and profitability (Belhabib et al. 2016; Mabe and Asase 2020). Rapid degradation and shrinkage of wetland resources in the past few decades has led aquatic weed infestation. Aquatic macrophyte infestation in Indian floodplain wetlands is posing serious challenges to their ecological and economic functioning, necessitating serious attention for their control and management for sustaining ecosystem services provided by these resources (Sarkar et al. 2021b).

Grass carp (Ctenopharyngodon idella) is a large, herbivorous fish native to eastern Asia (Froese and Pauly 2005). It is the most produced freshwater species globally, providing inexpensive and high-quality animal protein for consumers (Tian et al. 2020). Grass carp has been widely introduced throughout the world for aquatic weed control (Pipalova 2006). In natural systems, they feed almost exclusively on macrophytes from one month of age (Cudmore and Mandrak 2004). Daily macrophyte consumption can be as high as $100 \%$ of body weight per day (van der Lee et al. 2017). About $65 \%$ of the weeds are digested and rest released as dense pellets that act as "green manure" for the water body (Thomas 2007). Grass carp has been effectively used as biocontrol agent of aquatic weed species such as Potamogeton sp, Myriophyllum sp and Hydrilla sp (Cooke et al. 2005). In most instances, young grass carp are introduced (Hanlon et al. 2000) and are effective in eradication even in relatively low densities of 50 juvenile carp/ha (van Dyke et al. 1984). The benefits of using grass carp as biocontrol include its ability to control a wide variety of submersed and floating vegetation, longevity of the method owing to constant feeding activity for long duration, low investments and additional income from conversion of weed biomass to protein food in form of fish (Kirkagac and Demir 2004). In India though several studies explore carp based composite fish culture in ponds and tanks, however its importance and efficacy in wetland fisheries and enclosures have not been explored systematically.

Beledanga wetland is an oxbow lake located in lower Gangetic basin of North 24 Parganas district in West Bengal. Fisheries of the wetland is governed by a locally managed Fishermen Co-Operative Society (FCS). The fishing activities are the main source of income for 176 families. The area of the wetland has significantly decreased from 161.40acre (65.15ha) in 1980 to 113.67 (46.0ha) in 2020 over the last two decade owing to encroachment, water stress, macrophyte infestation and sedimentation aggravated by the climate change scenario in the State. The shrinkage of area, habitat modification and closure of link channel owing to reduced flows and sedimentation has significantly affected fish diversity and production from the wetland. To sustain livelihood of the fishers, FCS is practicing culture-based fisheries with Indian and exotic carps. 
Pen culture is an effective climate resilient adaptation strategy and an ideal technology for insitu seed raising for culture based fisheries (CBF) as well as table fish production in floodplain wetlands of India (Das et al. 2017a,b; Sarkar et al. 2021a; Paul et al. 2019, 2020). The strategic plan for inland fisheries development emphasizes on sustainable enhancement through implementation of region specific technologies in India (Das et al. 2021). The insitu raising of seed can address the issues of absence of rearing facilities near open water bodies and mortality in transporting bigger size fingerlings required for CBF. Insitu rearing of seed in pens and simultaneous release in wetlands lead to better survival (Roy and Hassan 2013). In this backdrop pen culture of grass carp along with Indian Major Carps (IMCs) was undertaken in the Beledanga wetland in participatory mode with the FCS. The aim of the study was to demonstrate efficacy of the pen culture in the wetland for raising advanced fingerlings of carps as stocking material for CBF and to integrate grass carp as important component of CBF as effective biocontrol for macrophyte management and enhanced fish production through biological conversion of macrophyte to protein food.

\section{Material And Methods}

\section{Study area}

The pen culture was demonstrated in a seasonally open wetland Beledanga, a cut off meander of River Ichamati situated in North 24 Parganas district of West Bengal. The GIS map was prepared using Arc GIS10.2.1 for land use patterns taking images from Google Earth. The effective water area of the wetland is 46 ha (Fig. 1). The fish stocking, production and revenue data was procured from records maintained by Beledanga FCS.

\section{Pen culture}

In the present study, HDPE knotless webbing net ( $3 \mathrm{~mm}$ mesh size) was used for constructing pen wall. Polypropylene ropes of $6 \mathrm{~mm}$ diameter were used for holding the net walls in shape supported by 10 feet long round strong and rigid FRP poles with perforations at regular intervals for tying with net wall. No bamboo was used in the pen structure and construction for increased longevity of the structure in water. The pen was installed in marginal area of the wetland where minimum water depth was $1 \mathrm{~m}$. The size of each pen unit was 0.1 ha. Indian major carps Labeo catla, L. rohita and Cirrhinus mrigala of initial size $6.28 \pm 0.23 \mathrm{~g}, 5.1 \pm 0.12 \mathrm{~g}$ and $3.5 \pm 0.08 \mathrm{~g}$ respectively were stocked at the ratio of $4: 3: 3$ at the rate of 20 no. $/ \mathrm{m}^{2}$ each in pens in triplicate. Grass carp of initial size $7.1 \pm 0.42 \mathrm{~g}$ were stocked at the rate of 20 no. $/ \mathrm{m}^{2}$ in duplicate. The fishes were fed with pelleted feed (crude protein $28 \%$, fat $5 \%$ ) twice a day at the rate of $2-3 \%$ of body weight per day. The seed was overwintered in pen culture duration was 90 days from November 2019-January 2020. After 90 days the advanced fingerlings produced were released in the wetland proper

The cost of pen, feed, seed and advanced fingerlings produced in the pens were estimated and benefit cost ratio (BC ratio) were used to estimate the economic viability of the pen culture. 


\section{B: $\mathrm{C}$ ratio $=[$ Total benefits $/$ Total cost $]$}

\section{Growth parameters}

Survival rate in each pen was calculated as:

Survival $(\%)=[$ Total number of fingerlings harvested/ Total number of fingerlings stocked] $\times 100$

Weight gain, specific growth rate (SGR), feed conversion ratio (FCR), feed conversion efficiency (FCE) and protein efficiency ratio (PER) were estimated as:

Weight gain $=[$ Final weight $(\mathrm{g})-$ Initial weight $(\mathrm{g})]$

SGR $(\% /$ day $)=[\ln ($ Final weight $)-\ln ($ Initial weight $)] /$ Culture duration in days $]$ x 100

$A D G=[$ Wet weight gain $(\mathrm{g}) /$ Culture duration in days $]$

FCR $=[$ Feed fed (dry weight)/ Wet weight gain $]$

FCE $=[$ Wet weight gain/ Feed fed (dry weight)]

PER $=[$ Net wet weight gain / Crude protein fed]

Since it was difficult to estimate the amount of feed consumed by different species in pens, the combined feeding efficiency (FCR, FER) were calculated for IMCs.

\section{Environmental parameters}

The climate data (air temperature and rainfall) for the study area (North 24 Parganas) was procured from Indian Meteorological Department (IMD). The water quality parameters were monitored monthly from pens, outside and $100 \mathrm{~m}$ away from pen site $(n=3)$ following the standard methods (APHA, 2012) to study impact of pen culture activities on wetland ecology.

\section{Statistical analysis}

All growth data were analysed in SPSS software (Version 14) for Windows. Average value pertaining to growth of a species in each pen was treated as independent treatment and mean \pm SE was estimated. The water quality data were analysed using one-way ANOVA. Significant differences between means of water quality parameters were evaluated using Duncan's multiple range test at $5 \%$ level of significance $(p<0.05)$.

\section{Results}

The growth performance of the IMCs during the experimental period is presented in Table 1. Among IMCs $L$. catla showed maximum growth in terms of weight gain, average daily growth and specific growth rate followed by $L$. rohita and $C$. mrigala. The survival rate showed ranged from $70 \%$ in $C$. mrigala to $81 \%$ in $L$. catla. The overall survival rate for IMCs was $76.8 \%$ in the pens. The FCR, PER and FCE calculated based 
on total feed given and total biomass achieved from each IMC culture pen were $2.76 \pm 0.15,1.30 \pm 0.06$, $0.37 \pm 0.02$ respectively. Among IMCs, the growth performance and survival rate of $L$. catla was significantly higher than $L$. rohita and $C$. mrigala. Grass carp $C$. idella attained average weight of $39.20 \pm 1.90$ during the 90 -day culture period with survival rate of $78.3 \%$. The feed utilization efficiency in terms of FCR, PER and FCE was $0.92 \pm 0.02,3.50 \pm 0.17$ and $1.14 \pm 0.03$ respectively. The growth performance and feed utilization efficiency of grass carp in pens was significantly better than IMCs (Table 1).

Table 1

Growth performance of carps in Pens at Beledanga wetland

\begin{tabular}{|lllll|}
\hline Species & Labeo catla & Labeo rohita & Cirrhinus mrigala & Ctenopharyngodon idella \\
\hline Initial weight (g) & $6.28 \pm 0.23$ & $5.1 \pm 0.12$ & $3.5 \pm 0.08$ & $7.1 \pm 0.42$ \\
\hline Final weight (g) & $25.13 \pm 1.70^{\mathrm{b}}$ & $18.11 \pm 0.63^{\mathrm{a}}$ & $14.53 \pm 0.87^{\mathrm{a}}$ & $39.20 \pm 1.90^{\mathrm{c}}$ \\
\hline Weight gain (g) & $18.85 \pm 1.72^{\mathrm{b}}$ & $12.99 \pm 0.65^{\mathrm{a}}$ & $10.97 \pm 0.80^{\mathrm{a}}$ & $32.12 \pm 1.68^{\mathrm{c}}$ \\
\hline Weight gain (\%) & $300.2 \pm 27.1^{\mathrm{a}}$ & $253.8 \pm 12.3^{\mathrm{a}}$ & $300.8 \pm 24.5^{\mathrm{a}}$ & $451.9 \pm 23.8^{\mathrm{b}}$ \\
\hline Survival (\%) & $81.77 \pm 0.66^{\mathrm{b}}$ & $76.67 \pm 2.02^{\mathrm{ab}}$ & $70.66 \pm 2.92^{\mathrm{a}}$ & $78.33 \pm 1.85^{\mathrm{b}}$ \\
\hline ADG & $0.21 \pm 0.01^{\mathrm{b}}$ & $0.14 \pm 0.01^{\mathrm{a}}$ & $0.12 \pm 0.01^{\mathrm{a}}$ & $0.35 \pm 0.02^{\mathrm{c}}$ \\
\hline SGR & $1.53 \pm 0.07^{\mathrm{a}}$ & $1.40 \pm 0.04^{\mathrm{a}}$ & $1.56 \pm 0.06^{\mathrm{a}}$ & $1.90 \pm 0.0 .05^{\mathrm{b}}$ \\
\hline FCR & $2.76 \pm 0.15^{\mathrm{b}}$ & $2.76 \pm 0.15^{\mathrm{b}}$ & $2.76 \pm 0.15^{\mathrm{b}}$ & $0.92 \pm 0.02^{\mathrm{a}}$ \\
\hline PER & $1.30 \pm 0.06^{\mathrm{a}}$ & $1.30 \pm 0.06^{\mathrm{a}}$ & $1.30 \pm 0.06^{\mathrm{a}}$ & $3.50 \pm 0.17^{\mathrm{b}}$ \\
\hline FCE & $0.37 \pm 0.02^{\mathrm{a}}$ & $0.37 \pm 0.02^{\mathrm{a}}$ & $0.37 \pm 0.02^{\mathrm{a}}$ & $1.14 \pm 0.03^{\mathrm{b}}$ \\
\hline Net Yield (kg) & $164.03 \pm 10.04^{\mathrm{b}}$ & $83.43 \pm 4.45^{\mathrm{a}}$ & $61.73 \pm 5.55^{\mathrm{a}}$ & $617.5 \pm 13.10^{\mathrm{c}}$ \\
\hline Values are Mean $\pm \mathrm{SD},(\mathrm{n}=3)$ & & & \\
\hline Different superscript in same row signify statistical differences at $95 \%$ confidence interval $(\mathrm{p}<0.05)$ \\
\hline
\end{tabular}

A net yield of $309.2 \mathrm{~kg}$ per pen (L. catla: $164.03 \pm 10.04 \mathrm{~kg}$; L. rohita: $83.43 \pm 4.45 \mathrm{~kg}$; C. mrigala: $61.73 \pm 5.55 \mathrm{~kg}$ ) was achieved from IMC pens while net yield per pen for grass carp was significantly higher $(617.5 \pm 13.10 \mathrm{~kg})$. The economics have been worked out taking into account possibility of three crops (seed) per year. The BC ratio for the culture was estimated to be 1.53 indicating its profitability. Feed accounted for $55 \%$ of recurring and $51.7 \%$ of the total cost per crop. Feed and seed cost formed over $93 \%$ of the total cost per crop (Table 2 ). 
Table 2

The water quality parameters during the seed raising

\begin{tabular}{|c|c|c|c|c|}
\hline Parameters & IMC pens & Grass carp pens & Reference site & p-Value \\
\hline Atmospheric temperature $\left({ }^{\circ} \mathrm{C}\right)$ & $25.23 \pm 4.20$ & $25.23 \pm 4.12$ & $25.43 \pm 4.05$ & 0.988 \\
\hline Water temperature $\left({ }^{\circ} \mathrm{C}\right)$ & $22.17 \pm 4.05$ & $22.40 \pm 3.90$ & $22.33 \pm 4.11$ & 0.997 \\
\hline $\mathrm{pH}$ & $7.43 \pm 0.25$ & $7.30 \pm 0.26$ & $7.63 \pm 0.25$ & 0.342 \\
\hline Dissolved oxygen $\left(\mathrm{mgL}^{-1}\right)$ & $7.13 \pm 0.30$ & $7.06 \pm 0.20$ & $7.53 \pm 0.31$ & 0.163 \\
\hline Conductivity $\left(\mu \mathrm{Scm}^{-1}\right)$ & $464.67 \pm 15.82$ & $467.0 \pm 15.01$ & $474.33 \pm 18.00$ & 0.761 \\
\hline Total dissolved solids $\left(\mathrm{mgL}^{-1}\right)$ & $335.67 \pm 29.67$ & $334.64 \pm 29.28$ & $336.56 \pm 21.33$ & 0.997 \\
\hline Free Ammonia $\left(\mathrm{mgL}^{-1}\right)$ & $0.004 \pm 0.001$ & $0.004 \pm 0.001$ & $0.002 \pm 0.001$ & 0.567 \\
\hline Turbidity (NTU) & $34.06 \pm 1.59$ & $34.84 \pm 1.56$ & $34.92 \pm 1.56$ & 0.770 \\
\hline Total Hardness $\left(\mathrm{mgL}^{-1}\right)$ & $197.33 \pm 11.54$ & $202.0 \pm 10.58$ & $196.67 \pm 11.2$ & 0.746 \\
\hline Alkalinity $\left(\mathrm{mgL}^{-1}\right)$ & $236.0 \pm 8.71$ & $238.0 \pm 10.58$ & $224.67 \pm 12.84$ & 0.590 \\
\hline Total nitrogen $\left(\mathrm{mgL}^{-1}\right)$ & $0.042 \pm 0.003$ & $0.045 \pm 0.002$ & $0.041 \pm 0.001$ & 0.996 \\
\hline Nitrate $\left(\mathrm{mgL}^{-1}\right)$ & $0.014 \pm 0.002$ & $0.016 \pm 0.003$ & $0.011 \pm 0.004$ & 0.388 \\
\hline Phosphate-P $\left(\mathrm{mgL}^{-1}\right)$ & $0.131 \pm 0.034$ & $0.146 \pm 0.025$ & $0.127 \pm 0.031$ & 0.730 \\
\hline Calcium $\left(\mathrm{mgL}^{-1}\right)$ & $32.86 \pm 1.38$ & $32.22 \pm 0.78$ & $33.80 \pm 1.85$ & 0.079 \\
\hline Magnesium $\left(\mathrm{mgL}^{-1}\right)$ & $27.63 \pm 1.93$ & $26.30 \pm 1.27$ & $25.87 \pm 1.66$ & 0.444 \\
\hline Sulfate $\left(\mathrm{mgL}^{-1}\right)$ & $0.33 \pm 0.03$ & $0.32 \pm 0.04$ & $0.30 \pm 0.05$ & 0.786 \\
\hline Silicate-Si $\left(\mathrm{mgL}^{-1}\right)$ & $11.83 \pm 2.54$ & $12.33 \pm 2.97$ & $12.88 \pm 2.16$ & 0.884 \\
\hline Chlorophyll-a $\left(\mu \mathrm{gL}^{-1}\right)$ & $17.63 \pm 1.47$ & $18.63 \pm 1.37$ & $20.31 \pm 1.86$ & 0.191 \\
\hline \multicolumn{5}{|l|}{ Values are Mean $\pm S D,(n=3)$} \\
\hline
\end{tabular}

The water quality parameters recorded from pen culture site and reference wetland site are presented in Table 3. In the present study, most of the environmental parameters were well within range suitable for carp culture. The water quality parameters studies did not vary significantly $(p>0.05)$ between pen and reference sites. The dissolved oxygen, chlorophyll a and primary productivity levels in the pen culture sites were comparatively lower to reference site. The mean annual temperature in the study area (North 24 Parganas) shows increasing trend (Fig. 2) while mean annual precipitation shows decreasing trend (Fig. 3) in the last two decades. The land use pattern of the catchment of the Beledanga beel is presented 
pictorially in Fig. 1 and percentage utilization is presented in Fig. 4. The land use is dominated by agriculture $(52 \%)$, followed by natural vegetation (39\%).

Table 3

Economics of pen culture for raising advanced fingerlings of Carps

\begin{tabular}{|lll|}
\hline SI. No & Particulars & Amount (INR) \\
\hline 1 & Fixed cost & \\
\hline 1.1 & Pen cost (0.5ha CIFRI HDPE pen) @ 47685/0.1 ha unit & $2,38,375$ \\
1.6 & Maintenance charges/crop & 500 \\
\hline 1.7 & Fixed cost/crop (@3 crops/year) (life span: 5years) & 15892 \\
\hline 2 & Recurring cost & \\
\hline 2.1 & Cost of seed @160INR/kg & 106380 \\
\hline 2.2 & Cost of feed @35 INR/kg (CIFRI CAGE GROW) & 131250 \\
\hline 2.3 & Miscellaneous (Lime, prophylactics) & 500 \\
\hline 2.5 & Total recurring cost & 238130 \\
\hline 3 & Total cost per crop & 254022 \\
\hline 4 & Estimated cost of produced fingerlings & 388600 \\
\hline 5 & Net profit & 134578 \\
\hline 6 & Benefit Cost Ratio (BC) & 1.53 \\
\hline
\end{tabular}

The assessment of fish production from the Beledanga wetland before and after the intervention showed a jump of $24 \%$ from $21372.45 \mathrm{~kg}$ in $2019-20$ to $28307.75 \mathrm{~kg}$ in $2020-21$. The productivity of the wetland has increased from 356-472kg/ha/year. The revenue has increased from 18.79 lakh INR in 2019-20 to 27.66 lakh INR in $2020-2021$ registering a growth of $32 \%$ (Fig. 5). Grass carp contributed $20-22 \%$ of the total CBF production in the wetland in 2020-2021.

\section{Discussion}

The growth performance of the IMCs in pens varied species wise with $C$. idella showing maximum growth in terms of weight gain, average daily growth and specific growth rate followed by L. catla, L. rohita and C. mrigala. The survival rate was highest for $L$. catla. The higher growth rate and low FCR $(<1)$ of grass carp in pens might be attributed to utilization of macrophyte growth in the pens. The macrophyte growth in pens with IMC was much higher than in pens with grass carp. The growth and survival of carps in pen showed similar trend to growth of carps reported in pens installed in Assam and Uttar Pradesh (Bhattacharjya et al. 2015; Alam et al. 2017). The comparatively lower growth might be probably due to low temperature regime in the present study, as the aim was to overwinter the seed to release them in the open wetland to utilise primary productivity and achieve compensatory growth in the productive wetland 
in growing season. The growth performance of the seed may be better during warmer temperature regime due to higher metabolic rate, feed utilization and shorted culture period.

A net yield realized viz $309.2 \mathrm{~kg}$ advanced fingerlings per pen from IMC culture and $617.5 \pm 13.10 \mathrm{~kg}$ per pen from grass carp culture was released into wetland proper as an input for CBF. Carp seed can easily be reared in high stocking densities in pens with using supplementary feeding with artificial feed to achieve high production rates (Das et al. 2017b). The additional benefit for in situ raising of seed for CBF is lower mortality, low production cost. Moreover, carp fingerlings grown in pens and subsequently released into wetlands show better survival (Roy and Hassan 2013). The present study highlighted the efficacy of pen enclosure for seed raising in these weed choked, shallow wetlands in absence of nursery facilities. This pen culture technique has also been deemed useful for grow out of carps and conservation of autorecruiting small indigenous species in the wetlands of eastern and north-eastern India (Sarkar et al. 2019).

Marginal fishers are more likely to adopt an adaptation strategy if it is economically viable (Kijima et al. 2011). The economics have been worked out considering possibility of three crops (seed) per year and culturing IMCs in all three pens and grass carp in two pens. The BC ratio for the culture (1.53) indicated its economic viability. Feed and seed cost formed over $90 \%$ of the recurring cost. Utilizing all the pens for grass carp will give higher benefit cost ratio. The technological feasibility and economic viability of pen culture have been previously reported in wetlands of Uttar Pradesh, West Bengal, Assam and Manipur with BC ratio varying from 1.4 to 1.8 (Gorai et al. 2006; Roy and Hassan 2013; Bhattacharjya et al. 2015; Alam et al. 2017; Das et al. 2017a,b; Yengkokpam et al. 2019). The variation in profitability may be attributed to difference in seed size stocked, culture period and duration, type of feed used, habitat characteristics and climatic conditions.

In the present study, most of the water quality parameters did not vary significantly $(p>0.05)$ between pens and reference sites. This may be due to small-scale farming. The lower plankton abundance and chlorophyll a level in the pens may be due to grazing of plankton by the stocked fishes and lower dissolved oxygen can be related to respiration. Most of the environmental parameters were well within range suitable for carp culture.

The mean annual temperature in the district of North 24 Parganas shows increasing trend while precipitation shows decreasing trend in the last two decades. Climate change trends along 4 major river basins viz. Ganga, Brahmaputra, Mahanadi, Cauvery show similar climatic trend (ICAR-CIFRI 2016; Sharma et al. 2015; Sarkar et al. 2019) in the last three decades. The climatic parameters have direct bearing on growth of species in floodplain wetlands affecting its production (Karnatak et al. 2020). The climatic variations along with overexploitation and habitat may be some of the major reasons for declining natural fish production and diminishing fish diversity in this wetland. The catchment is dominated by agriculture activities, which might be major source of nutrients through runoff reflected in the nutrient status (eutrophic) and primary productivity. The agriculture in the catchment is also one of the major cause of water abstraction from the wetland (Sarkar et al. 2020a). Paddy and Jute are major 
water intensive crops cultivated in the catchment fulfilling $30-40 \%$ of the water requirement from the wetland. Further jute retting in the wetland causes deterioration of water quality during monsoon months (July-September) (Fig. 6). This requires integrated wetland management interventions like use of water efficient irrigation system (drip, sprinkler) to reduce water abstraction and cropping of low water requiring crops like oil seeds, pulse and other cash crops. Promotion of organic farming in the catchment can control eutrophication of the wetland and promote food safety (Hassan et al. 2015).

The fish production from the studied wetland before and after the intervention showed a jump of $24 \%$ within one year. The productivity of the wetland has increased significantly from $356-472 \mathrm{~kg} / \mathrm{ha} / \mathrm{year}$, while revenue increased to the tune of $32 \%$. Grass carp contribution to total catch increased from $8-10 \%$ to $20-22 \%$. The stakeholders involved in routine monitoring of the wetland resources and fishing activities state that $80-85 \%$ of the wetland is infested with aquatic macrophytes including floating, submerged and emergent varieties. They opined that the grass carp stocked could utilise $40-45 \%$ of the macrophytes. The growth of the stocked grass carp was 0.8 to $1 \mathrm{~kg}$ within 6 month and 2-2.3kg within a year. Grass carp feeds preferably on submerged, rooted emergent vegetation (Swanson and Bergersen 1988) and can consume macrophytes up to $100 \%$ of body weight per day (van der Lee et al. 2017). Although in pond ecosystems they effectively control macrophytes at relatively low densities of 50 juvenile carp/ha (van Dyke et al. 1984); however the densities required to manage weed choked floodplain wetlands may be far more. In the present study grass carp stocking at the rate of $360 \mathrm{fish} / \mathrm{ha}$ could aid in utilization of approximately $40-45 \%$ of the macrophyte biomass, leaving further scope for fisheries enhancement through incorporation of herbivorous and macrophyte utilizing fish species like grass carp. There is a need to optimize their stocking densities based on area of wetland, type of macrophyte infestation, ecosystem type and their market demand. The production of these fishes in pens and its subsequent release in wetlands will not only boost carp fish production from the wetland but will not only reduce cost of seed for CBF. The growth performance and survival of grass carp indicate suitability of pens for their culture. Evidently, integration of grass carp will not only aid in ecofriendly macrophyte management in the wetlands but will also cater to nutritional and livelihood security of the fishers in face of changing climate by utilizing natural productivity converting weed biomass to protein food in form of fish.

\section{Declarations}

\section{Ethics approval and consent to participate}

The Institute Research Committee (IRC) of ICAR-Central Inland Fisheries Research Institute, Kolkata considering the animal care and ethical issues approved the research program and sampling methodology.

The authors consent to participate in the study.

\section{Consent for publication}

All the authors consent to publication of the study. 
Availability of data and materials

The original data presented in the study are available with the corresponding author and PI of the project the study is part of.

\section{Competing interests}

The authors declare no conflict of interest.

\section{Funding}

The study was funded by Indian Council of Agricultural Research, New Delhi.

\section{Authors' contributions}

\begin{tabular}{|ll|}
\hline Name of the author & Type of contribution \\
\hline Gunjan Karnatak & $\begin{array}{l}\text { Methodology, execution of growth trial, recording onsite water and soil } \\
\text { parameters, MS preparation }\end{array}$ \\
\hline Basanta Kumar Das & Conceptualization, overall supervision and project administration \\
\hline Uttam Kumar Sarkar & Data visualization and presentation \\
\hline Simanku Borah & Data curation and MS preparation \\
\hline Aparna Roy & Collection and analysis of fish capture data \\
\hline Pranay Parida & Assistance in statistical analysis of data \\
\hline Lianthuamluaia & Water quality analysis \\
\hline Archan Kanti Das & Guidance on pen culture management at field \\
\hline Bijay Kumar Behera & Reviewing and Editing MS \\
\hline Arun Pandit & Reviewing and Editing MS \\
\hline Amiya Sahoo & Reviewing and Editing MS \\
\hline $\begin{array}{l}\text { Birendra Kumar } \\
\text { Bhattacharjya }\end{array}$ & Reviewing and Editing MS \\
\hline Sangeeta Chakraborty, & Management of pen farm \\
\hline Purna Chandra & Assistance in collection of samples \\
\hline
\end{tabular}

\section{Acknowledgement}

The authors acknowledge funding support from WorldFish under the ICAR-WorldFish collaborative (W-3) project "Small-scale fisheries in wetlands for livelihood and nutritional security". The authors acknowledge NICRA project for providing climatic data of the study area. Participation and cooperation 
of the Beledanga fisheries cooperative society for providing data and implementation of project activities in co-management mode is greatly acknowledged.

\section{References}

1. Alam A, Joshi KD, Das SCS, Jha DN, Srivastava K, Kumar V, Bhattacharjya BK (2017) Enhancing fish productivity through pen culture: a case study in Sareni wetland of Uttar Pradesh. Indian J Fish 64:8-13

2. Belhabib D, Lam VW, Cheung WW (2016) Overview of West African fisheries under climate change: Impacts, vulnerabilities and adaptive responses of the artisanal and industrial sectors. Mar Pol 71:15-28

3. Cooke GD, Welch EB, Peterson S, Nichols SA (2005) Restoration and Management of Lakes and Reservoirs. CRC Press, Taylor and Francis Group, Boca Raton

4. Cudmore B, Mandrak NE (2004) Biological synopsis of grass carp (Ctenopharyngodon idella). Canadian Manuscript Report of Fisheries and Aquatic Sciences 2705. Fisheries and Oceans Canada

5. Das BK, Sarkar UK, Samanta S, Das AK, Hassan MA (2021) Strategic plan for Inland Open Water Fisheries Development under PMMSY. ICAR-Central Inland Fisheries Research Institute, Kolkata

6. Das A, Bhattacharjya BK, Goswami SN, Sawant PB, Debnath D, Yengkokpam S, Das A, Kakati A, Sarma KK, Chadha NK, Verma AK (2017b) Assessment of economic feasibility of pen aquaculture technology in floodplain wetlands (beels) of Assam, India. Indian J Fish 64:1-7

7. Das SCS, Alam A, Jha DN, Kumar V, Srivastava K, Bhattacharjya BK (2017a) Raising of stocking materials in pen enclosure in a floodplain wetland of Uttar Pradesh. J Inland Fish Soc India 49:1521

8. Froese R, Pauly D (2005) FishBase. www.fishbase.org

9. Gorai BK, Sugunan VV, Jha BC (2006) Raising of stocking materials of Indian major carps in pen enclosures in selected wetlands of Assam, India. Asian Fish Sci 19:185-197

10. Hanlon SG, Hoyer MV, Cichra CE, Canfield DE Jr (2000) Evaluation of macrophyte control in 38 Florida lakes using triploid grass carp. J Aquat Plant Manag 38:48-54

11. Hassan MA, Mishal P, Karnatak G, Aftabuddin Md, Meena DK, Sandhya KM, Lianthuamluaia L (2015) Ecosystem based integrated wetland management. ICAR-Central Inland Fisheries Research Institute, Kolkata

12. ICAR-CIFRI (2016) Annual Report 2015-16. ICAR-Central Inland Fisheries Research Institute, Kolkata

13. Jude DJ, Pappas J (1992) Fish utilization of Great Lakes coastal wetlands. J Great Lakes Res 18:651-672

14. Karnatak G, Sarkar UK, Naskar M, Roy K, Gupta S, Nandy SK, Srivastava PK, Sarkar SD, Sudheesan D, Bose AK, Verma VK (2018) Understanding the role of climatic and environmental variables in gonadal maturation and spawning periodicity of spotted snakehead, Channa punctata (Bloch, 1793) in a tropical floodplain wetland, India. Environ Biol Fishes 101:595-607 
15. Kijima Y, Otsuka K, Sserunkuuma D (2011) An inquiry into constraints on a green revolution in SubSaharan Africa: the case of NERICA rice in Uganda. World Dev 39:77-86

16. Mabe FN, Asase A (2020) Climate change adaptation strategies and fish catchability: The case of inland artisanal fishers along the Volta Basin in Ghana. Fish Res 230:105675

17. MEA (Millennium Ecosystem Assessment) (2005) Ecosystems and human well-being: Synthesis. Island Press, Washington DC

18. Nag SK, Nandy SK, Roy K, Sarkar UK, Das BK (2019) Carbon balance of a sewage-fed aquaculture wetland. Wetl Ecol Manag 27:311-322

19. Paul TT, Kuberan G, Panikker P, Sudheesan D, Sarkar UK, Das BK (2019) Demonstration of a climate resilient multitrophic pen system in Vembanad lake, Kerala, India. World Aquaculture 3:56-58

20. Paul TT, Panikker P, Sarkar UK, Manoharan S, Kuberan G, Sreenath KR, Zachariah PU, Das BK (2020) Assessing vulnerability and adopting alternative climate resilient strategies for livelihood security and sustainable management of aquatic biodiversity of Vembanad lake in India. J Water Clim Change 12:1310-1326

21. Pipalova I (2006) A review a grass carp use for aquaculture weed control and its impact on water bodies. J Aquat Plant Manag 44:1-12

22. Roy A, Hassan MA (2013) Adoption of pen culture technology in wetlands of West Bengal, India. Fish Technol 50:342-346

23. Sarkar S, Sarkar UK, Ali S, Kumari S, Puthiyottil M (2021b) Status, ecological services and management of aquatic weeds of floodplain wetlands in India: An overview. Lakes and Reservoirs: Science, Policy and Management for Sustainable Use 26:76-91

24. Sarkar UK, Borah BC (2018) Flood plain wetland fisheries of India: with special reference to impact of climate change. Wetl Ecol Manag 26:1-15

25. Sarkar UK, Bakshi S, Lianthuamluaia L, Mishal P, Ghosh BD, Saha S, Karnatak G (2020b) Understanding enviro-climatological impact on fish biodiversity of the tropical floodplain wetlands for their sustainable management. Sustain Water Resour Manag 6:1-12

26. Sarkar UK, Mishal P, Borah S et al (2021a) Status, potential, prospects, and issues of floodplain wetland fisheries in India: synthesis and review for sustainable management. Rev Fish Sci Aquac 29:1-32

27. Sarkar UK, Nag SK, Das MK, Karnatak G, Sudheesan D (2016) Conserving wetlands-An effective climate change adaptation in India. ICAR-Central Inland Fisheries Research Institute, Kolkata

28. Sarkar UK, Saha S, Mishal P, Karnatak G, Das AK, Das BK, Meena DK, Lianthuamluaia L, Manna SK (2020a) Fisheries management of a sewage fed Gangetic floodplain wetland in the context of changing climate: A case study using multiple approaches. J Inland Fish Soc India 52:28-41

29. Sharma AP, Joshi KD, Naskar M, Das MK (2015) Inland fisheries \& climate Change: vulnerability and adaptation options. ICAR-Central Inland Fisheries Research Institute, Kolkata 
30. Sierszen ME, Morrice JA, Trebits AS, Hoffman JC (2012) A review of selected ecosystem service provided by coastal wetlands of the Laurentian Great Lakes. Aquat Ecosyst Health Manag 15:92106

31. Swanson ED, Bergersen EP (1988) Grass carp stocking model for coldwater lakes. N Am J Fish Manag 8:284-291

32. Tian J, Zhang J, Yu E, Sun J, Xia Y, Zhang K, Li ZF, Gong W, Wang G, Xie J (2020) Identification and analysis of lipid droplet-related proteome in the adipose tissue of grass carp (Ctenopharyngodon idella) under fed and starved conditions. Comp Biochem Physiol Part D Genom Proteom 36:100710

33. Trebitz AS, Hoffman JC (2015) Coastal wetlands support of Great Lakes fisheries: progress from concept to quantification. Trans Am Fish Soc 144:352-372

34. van der Lee AS, Johnson TB, Koops MA (2017) Bioenergetics modelling of grass carp: Estimated individual consumption and population impacts in Great Lakes wetlands. J Great Lake Res 43:308318

35. van Dyke JM, Leslie AJ Jr, Nall LE (1984) The effects of grass carp on the aquatic macrophytes of four Florida Lakes. J Aquat Plant Manag 22:87-95

36. Yengkokpam S, Debnath D, Bhattacharjya BK, Yadav AK, Das P, Sarma KK, Das BK (2019) Polyculture of Osteobrama belengari with major carps in pen enclosures in Takmu lake of Manipur. Indian J Fish $51: 125-132$

\section{Figures}




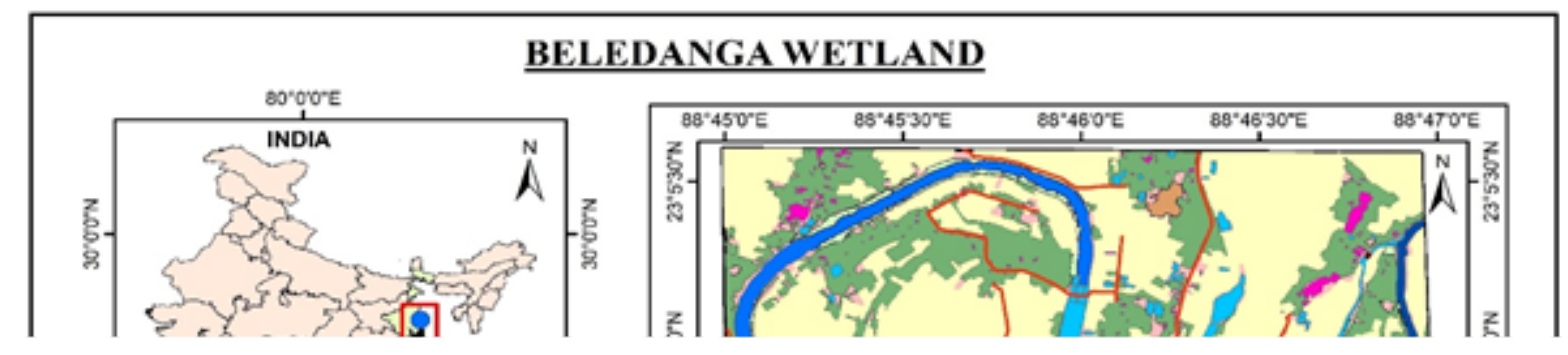

Figure 1

A view of study area and Pen culture site at Beledanga wetland, India 


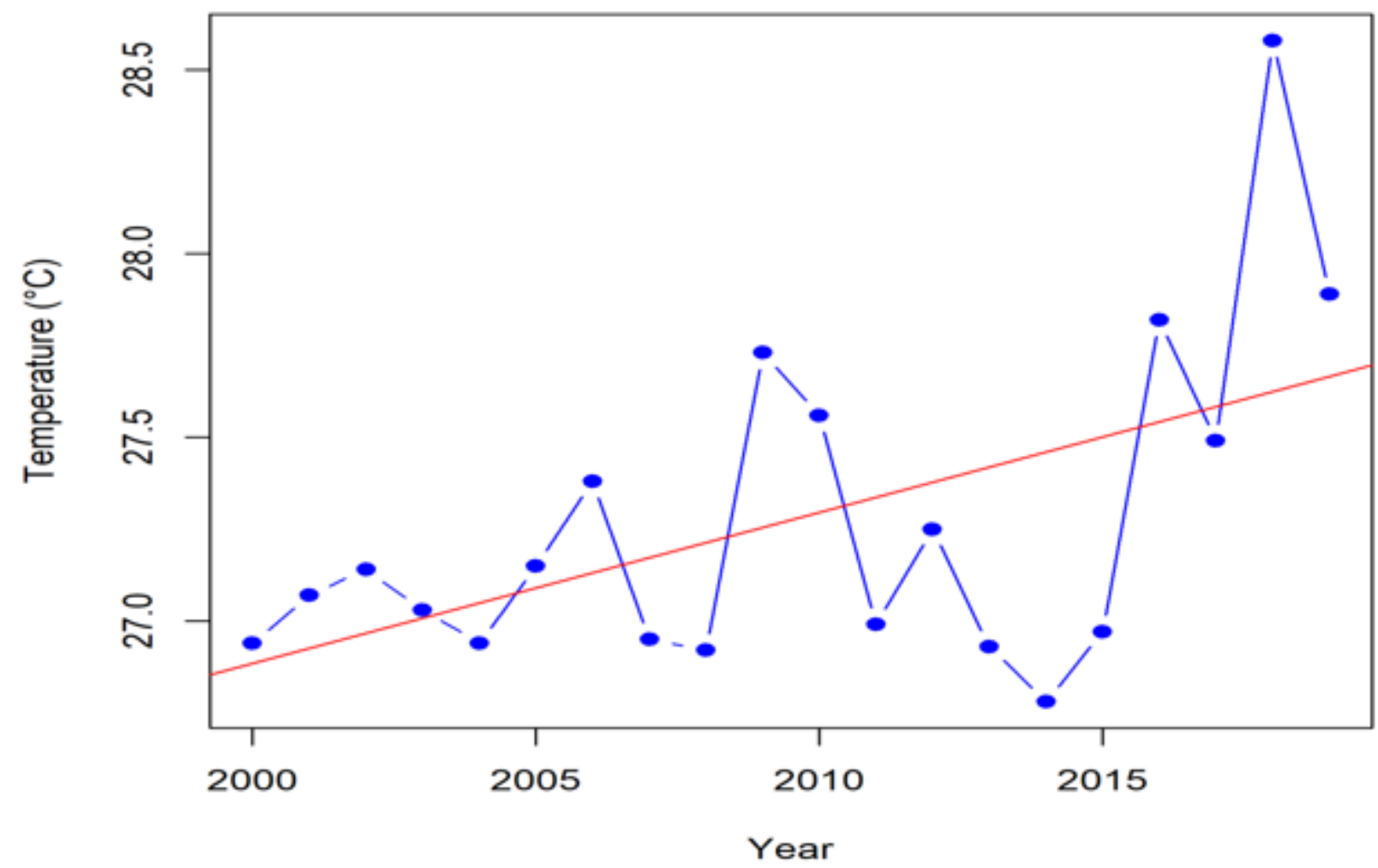

Figure 2

Mean air temperature trend in the North 24 Parganas district in the last two decades

Figure 3

Mean annual rainfall trend in the North 24 Parganas district in the last two decades 


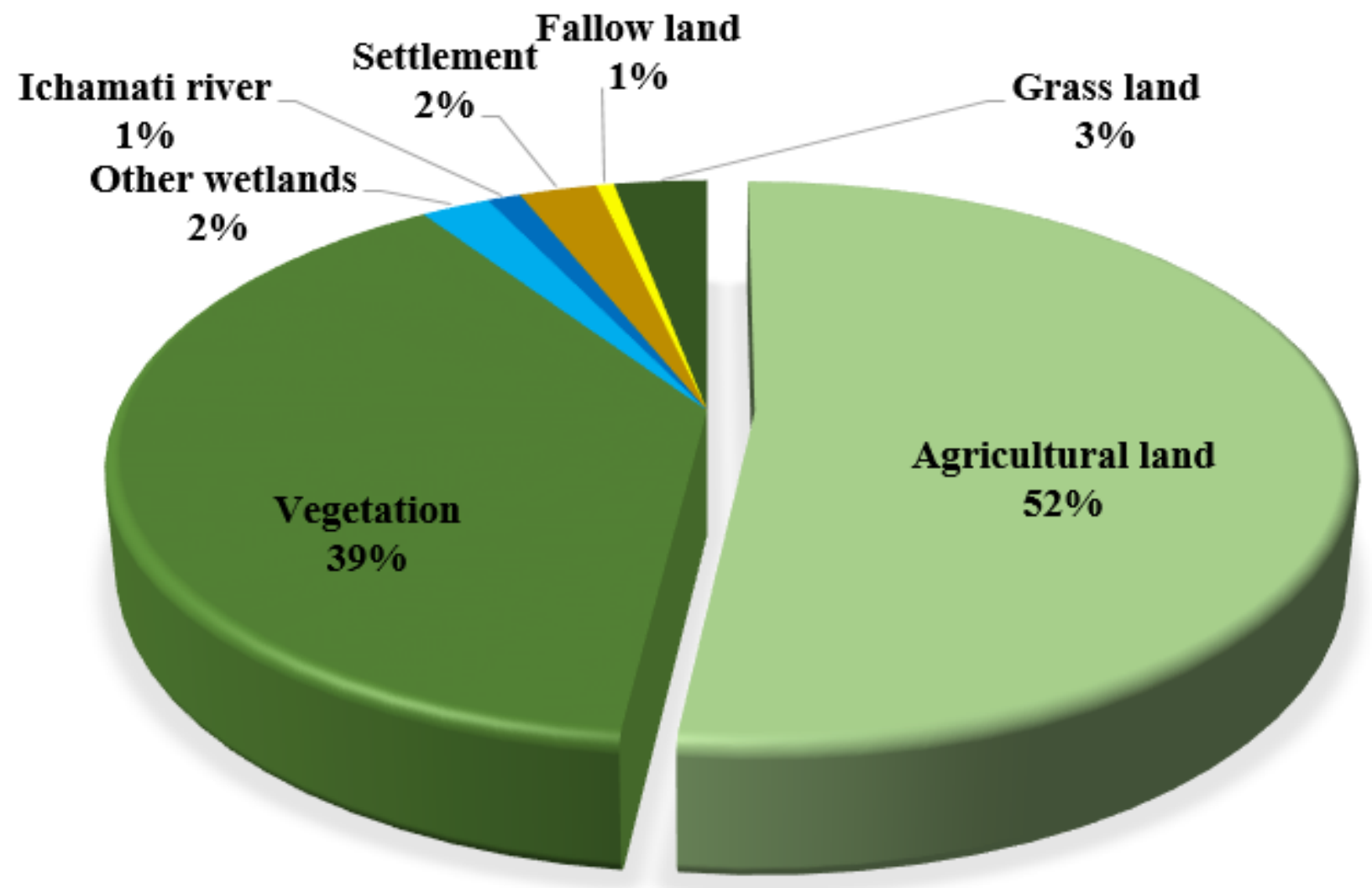

Figure 4

Land use pattern of Beledanga wetland catchment

Figure 5

Enhancement in fish yield and generation of revenue through fish sale in Beledanga wetland 


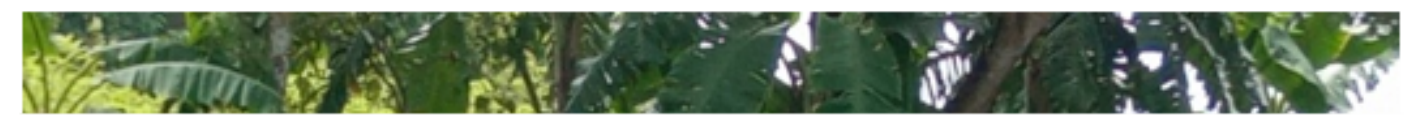

Figure 6

Jute cultivation and retting in the Beledanga wetland 